PT Tema broja

R. KARAMARKOVIĆ, Đ. NOVČIĆ, M. NIKOLIĆ,

M. KARAMARKOVIĆ, D. ŠIMUNOVIĆ

https://doi.org/10.24094/ptc.018.30.1.20

\title{
Eksperimentalno ispitivanje gasifikacionog kotla: dizajn komore za sagorevanje
}

S adašnja stremljenja u tehnici koja se bavi konstruisanjem uređaja i sistema za zadovoljenje potreba za toplotnom energijom teže korišćenju: 1) toplotnih izvora temperatura što je moguće bliže zahtevanim, 2) energetski najefikasnijih i ekološki najprihvatljivijih tehnologija transformacije, 3) obnovljivih izvora energije i 4) povezivanju energetskih i tehnoloških procesa putem pametnih mreža. Rezultat ovih stremljenja je: veće korišćenje otpadne toplote, toplotnih pumpi, kogeneracionih, trigene-racionih, hibridnih sistema, pametnih mreža i sl. Ova stremljenja su lako uočljiva na primeru istorijskog razvoja i definisanju budućih ciljeva sistema daljinskog grejanja [1]. U tehnologijma koje se razvijaju, biomasa bi trebala da zadrži ulogu značajnog energenta. U Republici Srbiji drvna biomasa se na godišnjem nivou trenutno koristi sa 1,021 Mtoe, dok je njen godišnji neiskorišćeni potencijal 0,509 Mtoe [2]. Ne postoji tačna procena kolika je efikasnost uređaja $i$ sistema koji koriste ovu biomasu.

\section{Uvod}

Proizvođači peći i kotlova na drvnu biomasu ulažu značajne napore na povećanje efikasnosti i smanjenje emisija zagađujućih materija. Drvna biomasa se koristi u obliku ogrevnog drveta, sečke, peleta i drvenog uglja. Ogrevno drvo je ekonomski najprihvatljivije od svih navedenih goriva. Osim cene, prednost ogrevnog drveta je niža emisija posrednih zagađivača zbog kraćeg transporta i manje potrebe za procesuiranjem tokom proizvodnje. Nasuprot prednostima, glavni nedostaci ogrevnog drveta su: otežana kontrola procesa sagorevanja i veće emisije zagađujućih materija $u$ atmosferu. Radi smanjenja emisija, drvo se sagoreva višestepeno ili se kotlovi i peći uparuju sa akumulatorima toplote radi uspostavljanja stacionarnog režima sagorevanja $[3,4]$.

Predmet rada je ispitivanje i konstruisanje kotlova za višestepeno sagorevanje ogrevnog drveta. U prvom stepenu drvo nepotpuno sagoreva (gasifikuje se), dok se u drugom gorivi gas sagoreva. Zone gasifikacije i sagorevanja su u gasifikacionim kotlovima fizički odvojene. Principske šeme najčešće korišćenih konstrukcija prikazane su na slici 1. Na njima je primenjena isključivo istosmerna gasifikacija drveta (vazduh i gorivi gas struje u istom smeru), i u svim prikazanim konstrukcijamakomora za gasifikaciju (koja je ujedno i bunker za gorivo) je najčešće iznad komore za sagorevanja gorivog gasa (ložište kotla). Osim prikazanih konstrukcija, postoje konstrukcije sa poprečnom i suprotnosmernom gasifikacijom [5], kao i kod reaktora za gasifikaciju u nepokretnom sloju. Prikazane konstrukcije dominiraju na tržištu zbog pouzdanosti, razrađenog principa (proizvođači najlakše prihvataju uspešno razrađene principe), mogućnosti sagorevanja nešto vlažnijeg drveta i stabilnog strujanja vazduha i gasa kroz zonu gasifikacije. Konstrukcija prikazana na slici 1. A je tehnički najjednostavnija, ali i ekološki najneprihvatljivija. Njen nedostatak je uzrokovan velikom količinom čvrstih čestica u gasu koji sagoreva. Ove čestice padaju na dno ložišta, vrlo brzo se hlade i uzrokuju veće emisije ugljenmonoksida (CO), veću količinu nesagorelog ugljenika u pepelu i veću količinu čestica u dimnom gasu. Ovaj problem je izraženiji pri smanjivanju količine goriva u komori za gasifikaciju (pozicija 1 na slici 1.) jer se tada smanjuje otpor strujanja vazduha i gasa. Zbog toga je veći deo ložišnog prostora prekriven vatrostalnom keramikom kao u konstrukciji prikazanoj na slici 1. B, koju nalazimo u referencama $[6,7,8]$.

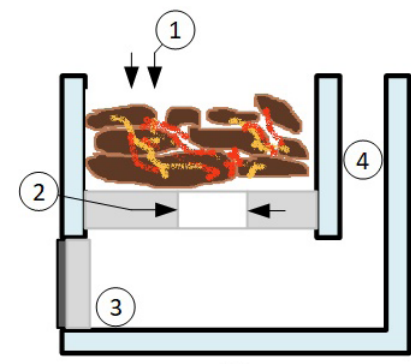

(1) A)

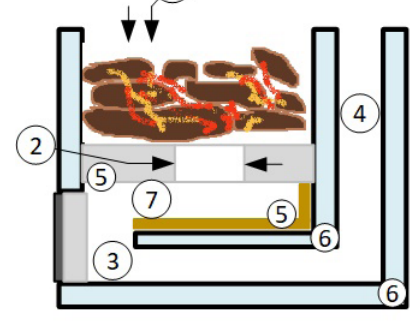

C)

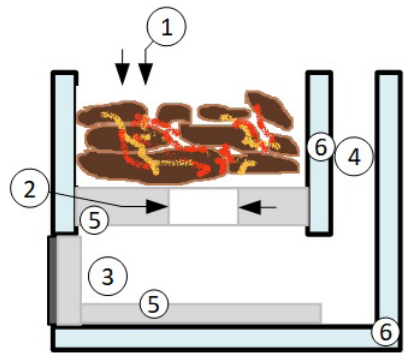

(1) B)

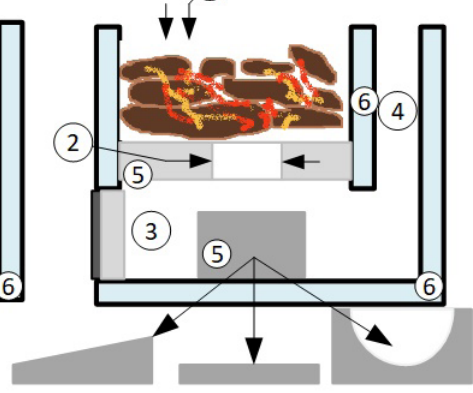

D)
Slika 1: Analizirane konstrukcije gasifikacionih kotlova sa istosmernom gasifikacijom ogrevnog drveta. 1 - primarni vazduh (za gasifikaciju) i komora za gasifikaciju, 2 - sekundarni vazduh (za sagorevanje gorivog gasa), 3 - komora za sago-revanje, 4 - konvektivni deo kotla, 5 - elementi od vatrostalne keramike, 6 - kanali za strujanje vode, 7 - međukomora 
Slika 1. C prikazuje ispitivanu konstrukciju. Ona je često primenjivana što se može videti u referenci [9]. Ispitivanja koja se prikazuju, sprovedena su sa prirodno sušenim bukovim drvetom shodno standardu EN 303-5:2012. Konstrukcija se pokazala dobrom ali je, kao što će se videti, pokazala i izvesne nedostatke. Radi njenog konstrukcionog pojednostavljenja i unapređenja sagorevanja i razme-ne toplote $u$ radu su analizirane mogućnosti primene osnovne konstrukcije sa dodatkom jednog umetka od vatrostalne opeke. Slika 1. D prikazuje princip konstrukcije sa vatrostalnim umetkom. Ovaj tip konsturkcije se sreće u referencama $[10,11]$. Konstrukcije sa umecima koje se analiziraju u radu su izrađene ali nisu ispitane. Pre njihove izrade umeci od vatrostalne opeke u ložištu su numerički analizirani pomoću numeričkog alata CFD. Ova analiza se takođe prikazuje u radu.

\section{Ispitivanje gasifikacionog kotla}

Ispitivanja gasifikacionog kotla na ogrevno drvo nazivne snage 20 kW izvedena su u laboratoriji kompanije „Radijator inženjering“ u Kraljevu [12]. Izgled kotla je prikazan na slici 2. dok je na slici 3. prikazan crtež ploča od vatrostalne opeke koja deli gasifikacionu komoru i ložište kotla.

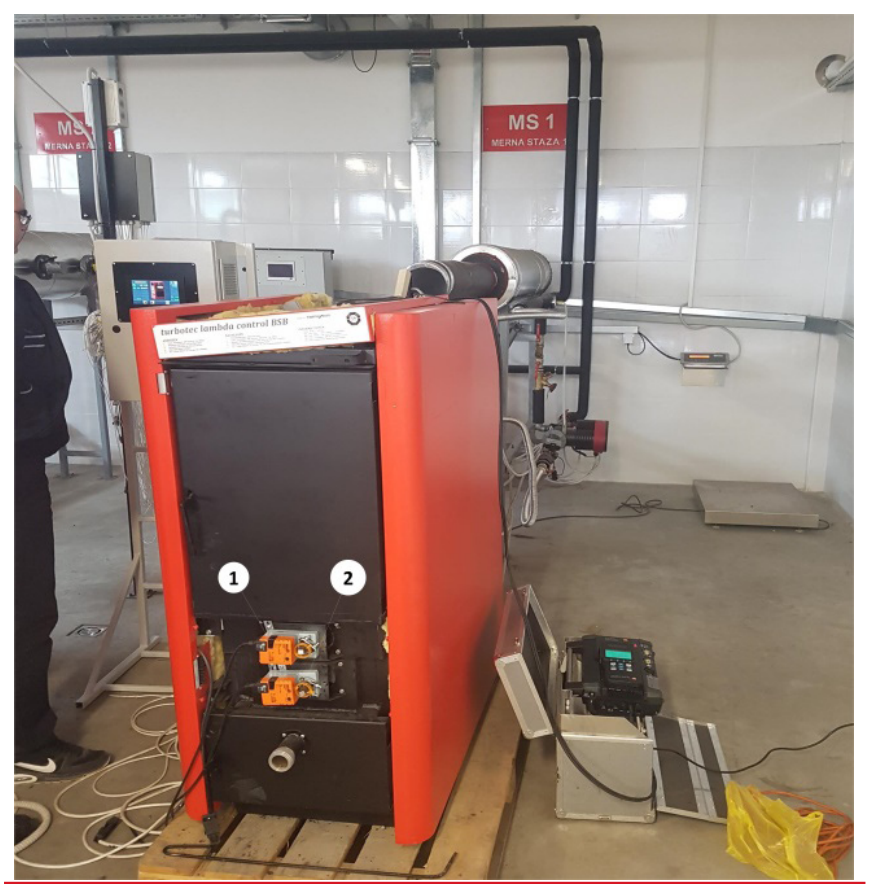

Slika 2: Detalj sa ispitivanje toplovodnog gasifikacionog kotla. 1 - električni motor za regulaciju protoka primarnog vazduha, 2 - električni motor za regulaciju protoka sekundarnog vazduha

Slika 1. C pokazuje princip konstrukcije ispitivanog kotla. U gasifikacionom delu kotla (pozicija 1) strujeći istosmerno vazduh nepotpuno sagoreva ogrevno drvo. Količina primarnog vazduha se kreće $\mathrm{u}$ opsegu od 1,5 do 1,55 m³ $/ \mathrm{kg}$ drveta koje sagoreva i kontrolisana je pomoću regulacione klapne pokretane pomoću elektromotora (pozicija 1 na slici 2.). Po izlasku iz zone gasifikacije, gas dogoreva u međukomori 7. Zonu gasifikacije i međukomoru deli ploča od vatro- stalne keramike (prikazana na slici 3.), čija je uloga da: ograniči zonu gasifikacije i ložište, drži gorivo koje se sagoreva, omogući uvođenje i predgrevanje sekundarnog vazduha, i obezbedi adekvatno mešanje gasa iz gasifikacione zone i vazduha za sagorevanje. $U$ ispitivanoj konstrukciji kanali za uvođenje sekundarnog vazduha su kružnog oblika i njihovi su detalji prikazani na slici 3. Sekundarni vazduh se, kao i primarni, kontroliše pomoću klapne pokretane elektromotorom prikazanim na poziciji 2 na slici 2 . Količina sekundarnog vazduha je tokom ispitivanja kontrolisana tako da količina kiseonika $\mathrm{O} 2 \mathrm{u}$ dimnom gasu na izlazu iz kotla bude 7 zap\%.

Iz međukomore 7 (na slici 1. C, videti i sliku 3. A) dimni gas ulazi u ložište 3, u kome je smeštena pepeljara i zračenjem i konvekcijom predaje toplotu vodi. Kod isptivanog kotla, kao i kod većine kotlova na čvrstu biomasu, dimni gas u ložištu preko pločastih površina predaje toplotu vodi. Iz ložišta, dimni gas ulazi u konvektivni deo kotla 4 (konvekcija dominira u prenosu toplote), koji čine dimovodne cevi. Zbog prinudnog strujanja dimni gas sa sobom nosi veću količinu letećih čestica. U kotlovima ovog tipa, turbulatori u konvektivnom delu kotla su obavezni i imaju trostruku ulogu: povećavaju turbulencije (koeficijent prelaza toplote), zadržavaju čestice i služe za njihovo otresanje. Koncept gasifikacionih kotlova, prikazan na slici 1., se primenjuje i zato što omogućava jednostavno uklanjanje pepela i nesagorelog ostatka iz ložišta i konvektivnog dela kotla.

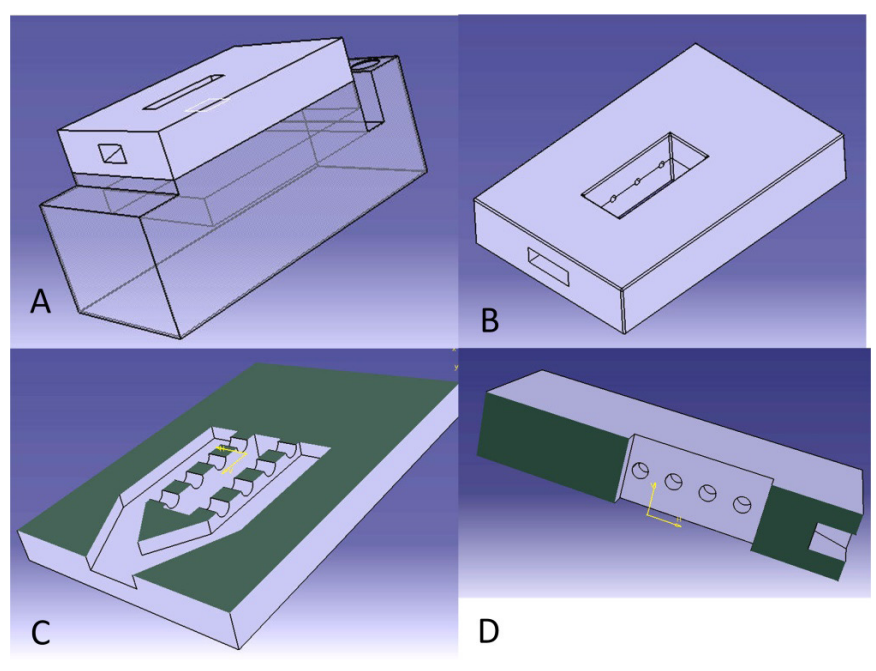

Slika 3: Izgled dela ispitivanog kotla u kome sagoreva gorivi gas. A - izometrijski detalj ložišta, B - keramička ploča koja deli zonu gasifikacije i zonu sagorevanja gorivog gasa, C i D - poprečni preseci keramičke ploče

\subsection{Ispitno gorivo}

Bukove cepanice različitih dužina su korišćene kao ispitno gorivo. Najgrublje rečeno, među cepanicama dominirali su komadi dužine $\sim 40 \mathrm{~cm}$. Njihova elementarna i tehnička analiza nije rađena već je sastav suvog bukovog drveta uzet sa baze podataka Phyllis2 [13] i prikazan u tabeli 1. Vlažnost goriva 19,3 mas\% je merena pomoću uređaja Testo 606-1 i određena je kao srednja aritmetička vrednost svih izmerenih vrednosti. Donja toplotna moć (LHV) ispitnog goriva je iznosila $13637 \mathrm{~kJ} / \mathrm{kg}$ i računata je na osnovu [14]: 


\section{PT Tema broja}

$\mathrm{LHV}=340 \mathrm{C}+1190(\mathrm{H}-\mathrm{O} / 8)+93 \mathrm{~S}-25 \mathrm{~W}$,

gde su C, H, O, S, W \% maseni udeli elemenata u vlažnoj masi goriva.

Tabela 1. Maseni sastav suve bukve [13]

\begin{tabular}{c|c|c|c|c|c|c|}
$\begin{array}{c}\mathbf{C} \\
\text { (mas\%) }\end{array}$ & $\begin{array}{c}\mathbf{H} \\
\text { (mas\%) }\end{array}$ & $\begin{array}{c}\mathbf{N} \\
\text { (mas\%) }\end{array}$ & $\begin{array}{c}\text { O } \\
\text { (mas\%) }\end{array}$ & $\begin{array}{c}\text { A } \\
\text { (mas\%) }\end{array}$ & $\begin{array}{c}\text { LHV } \\
(\mathbf{M J} / \mathbf{k g})\end{array}$ & $\begin{array}{c}\text { HHV } \\
(\mathbf{M J} / \mathbf{k g})\end{array}$ \\
\hline 48,06 & 5,87 & 0,2 & 45,35 & 0,52 & 14,97 & 16,38 \\
\hline
\end{tabular}

\subsection{Rezultati ispitivanja}

Tabela 2. prikazuje srednje rezultate merenja i mernu opremu koja je korišćena za njihovo dobijanje. Slike 4. i 5. prikazuju srednje minutne vrednosti sadržaja kiseonika $\mathrm{O}_{2} \mathrm{u}$ dimnom gasu i emisije ugljenmonoksida $\mathrm{CO}$ u mg/m $\mathrm{m}_{\mathrm{N}^{3}}$. Emisije CO i NOx date su za dimni gas na normalnim uslovima i referentni sadržaj kiseonika u suvom dimnom gasu od 13 zap $\%$.

Tokom ispitivanja kotao je radio sa prosečnom snagom od 19.97 $\mathrm{kW}$, što gotovo odgovara njegovoj nazivnoj snazi (20 kW). Na ovoj snazi kotao nema visok stepen korisnosti imajući u vidu da se temperatura produkata na izlazu kretala u opsegu od 160 do $180{ }^{\circ} \mathrm{C}$. Ovo je i tzv. podešeni opseg modulacije temperature na primenjenom sistemu automatske kontrole.

Tabela 2. Srednje vrednosti merenih veličina tokom ispitivanja.

\begin{tabular}{|c|c|c|c|}
\hline Merna veličina & Vrednost & $\begin{array}{l}\text { Jedinica } \\
\text { mere }\end{array}$ & Merni uređaj \\
\hline $\begin{array}{l}\text { O2 - u suvim prodkutima } \\
\text { sagorevanja }\end{array}$ & 6,76 & $\%$ & HORIBA VA-3000 \\
\hline $\begin{array}{l}\text { CO - u suvim produktima } \\
\text { sagorevanja sa referetnim } \\
\text { sadržajem kiseonika od } 13 \\
\text { zap\% }\end{array}$ & 622,97 & $\mathrm{mg} / \mathrm{Nm}^{3}$ & HORIBA VA-3000 \\
\hline $\begin{array}{l}\text { NOx - u suvim produktima } \\
\text { sagorevanja sa referetnim } \\
\text { sadržajem kiseonika od } 13 \\
\text { zap\% }\end{array}$ & 273,42 & $\mathrm{mg} / \mathrm{Nm}^{3}$ & HORIBA VA-3000 \\
\hline $\begin{array}{l}\text { pV-pritisak vode na izlazu } \\
\text { razvodnog voda tople vode } \\
\text { kotla }\end{array}$ & 1,69 & bar & $\begin{array}{c}\text { manometer BD } \\
\text { sensors }\end{array}$ \\
\hline $\begin{array}{l}\text { pR- pritisak vode na ulazu } \\
\text { povratnog voda tople vode } \\
\text { u kotao }\end{array}$ & 1,75 & bar & $\begin{array}{l}\text { manometer } \mathrm{BD} \\
\text { sensors }\end{array}$ \\
\hline $\begin{array}{l}\text { tV -temperatura tople vode } \\
\text { na izlazu iz kotla }\end{array}$ & 69,16 & ${ }^{\circ} \mathrm{C}$ & termometar \\
\hline $\begin{array}{l}\text { tR -temeratura tople vode na } \\
\text { ulazu u kotao }\end{array}$ & 51,56 & ${ }^{\circ} \mathrm{C}$ & termometar \\
\hline $\begin{array}{l}\text { dpF- srednja vrednost vuče } \\
\text { dimnjaka }\end{array}$ & 11,95 & $\mathrm{~Pa}$ & - \\
\hline Q - srednja snaga kotla & 19,97 & $\mathrm{~kW}$ & Calmstrup \\
\hline
\end{tabular}

Sistem automatskog upravljanja sagorevanjem kotla podešen je tako da se primarnim vazduhom upravlja na osnovu izlazne temperature vode iz kotla, a sekundarnim tako da količina kiseonika u produktima sagorevanja bude 7 zap\%. Primarni vazduh se uvodi na osnovu toplotne snage a sekundarni na osnovu merenja sadržaja kisonika u dimnom gasu. Srednja vrednost kiseonika tokom ispitivanja bila je 6,76 zap\% i imala je maksimalne vrednosti u istim vremenskim intervalima kao i emisija ugljenmonoksida (CO), što se može videti na slikama 4. i 5 .

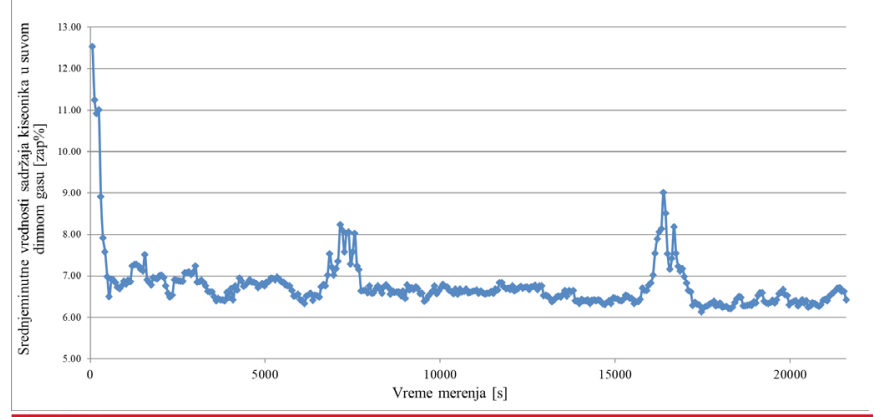

Slika 4: Promena srednje minutnih vrednosti sadržaja kiseonika u suvom dimnom gasu na normalnim uslovima

Sa slike 5. se uočavaju već pomenuta tri skoka koja utiču na srednju vrednost emisije CO uvećavajući je za oko $100 \mathrm{mg} / \mathrm{m}_{\mathrm{N}^{3}}$. Sve ostalo vreme kotao je radio stabilno sa približno stalnim emisijama CO.

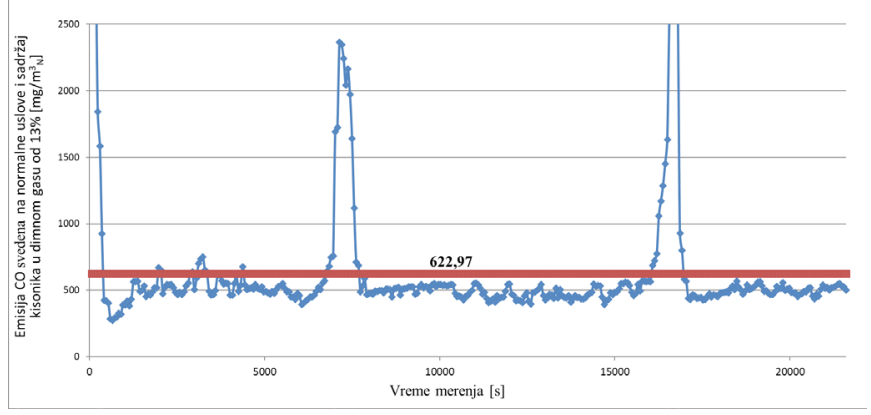

Slika 5: Promena srednjih minutnih vrednosti sadržaja ugljen monoksida $\mathrm{CO}$ u suvom dimnom gasu na normalnim uslovima i referentnim sadržajem kiseonika $\mathrm{O}_{2}$ od 13 zap\% u odnosu na srednju vrednost emisije CO $\left(622.97 \mathrm{mg} / \mathrm{m}_{\mathrm{N}^{3}}\right)$.

\section{Unapređenje sagorevanja i pojednostavljen- je konstrukcije kotla}

Ispitivani kotao je imao emisije CO koje odgovaraju klasi 5 (najviša klasa kod koje emisije CO treba da su niže od $700 \mathrm{mg} / \mathrm{m}_{\mathrm{N}^{3}}$ ) standarda EN 303-5. Međutim, ova emisija prevazilazi maksimalno dozvoljene vrednosti definisane $\mathrm{u}$ aneksu istog standarda za pojedine države. Bez obzira na formalni cilj proizvođača koji je vezan za pomenuti standard, cilj rada je da odgovori na pitanje kako unaprediti sagorevanje ispitivnog kotla zato što je na osnovu rezultata ispitivanja jasno je da postoji prostor za dalje smanjenje emisija CO i NOx. Ono se može ostvariti dvojako: izmenama u načinu rada postojeće konstrukcije ili konstruktivnim izmenama zone sagorevanja. Predlozi za oba načina daju se u nastavku rada. 


\subsection{Unapređenje sagorevanja postojeće konstrukcije kotla}

Slike 4. i 5. prikazuju da se prosečna emisija ugljenmonoksida (CO) može smanjiti ispod $500 \mathrm{mg} / \mathrm{m}_{\mathrm{N}^{3}}$ eliminisanjem maksimuma (skokova) koji se javljaju na početku rada i pri smanjivanju količine goriva u kotlu. Početni maksimum emisije CO se javlja zato što automatika kreće u regulaciju sa potpuno otvorenim klapnama primarnog i sekundarnog vazduha i treba joj vremena da se stabilizuje. Algoritam upravljanja je potrebno promeniti tako da sistem počinje upravljanje sa otvorenom klapnom primarnog vazduha i klapnom sekundarnog vazduha na radnom položaju iz stacionarnog (uobičajnog) radnog režima.

Maksimalne vrednosti emisija CO koji se javljaju tokom rada (videti sliku 5.) drugačije su prirode. Kada u kotlu, tj. u zoni gasifikacije (pozicija 1 na slici 1.) ostane malo goriva, tačnije kad je visina sloja goriva niža od nivoa na kom se ubacuje primarni vazduh, on kroz ovu komoru struji sa lakoćom pri nepromenjivom radu ventilatora za izbacivanje dimnog gasa iz kotla. Zbog manjeg otpora strujanju raste količina primarnog vazduha, koja uzrokuje intenzivnije sagorevanje u zoni gasifikacije i omogućava gasu da sa sobom transportuje veću količinu komadića čvrstog goriva (drveni ugalj) u međukomoru (pozicija 7 na slici 1., videti i sliku 3. A). Povećana količina produkata sagorevanja, deo koma-dića izbacuju iz međukomore $7 \mathrm{u}$ ložište 3 gde se oni naglo hlade. Zbog naglog snižavanja temperature i neadekvatnog opstrujavanja gasa dolazi do pojave nepotpunog sagorevanja i povećane emisije CO. Ove emisije CO je moguće sniziti takođe promenom algoritma upravljanja. U slučajevima kad pri zatvaranju klapne sekundarnog vazduha raste količina kiseonika u produktima sagorevanja, sistem automatskog upravljanja treba da smanjuje količinu primarnog vazduha zatvaranjem klapne primarnog vazduha ili smanjivanjem broja obrtaja odsisnog ventilatora dimnog gasa.

Emisije NOx i CO moguće je dodatno sniziti finim podešavanjem količine sekundarnog vazduha (u slučaju izvršenog eksperimenta srednja vrednost $\mathrm{O}_{2}$ je bila 6,76 zap\%). Naime, potrebni su brojni eksperimenti tako da se odredi sadržaj kiseonika u produktima sagorevanja pri kome su emisije $\mathrm{CO}$ i NOx najmanje.

\subsection{Promena konstrukcije ložišta kotla}

Izvršena ispitivanja su pokazala da je moguće dodatno smanjiti emisije CO i NOx, ali je iz njih očigledno da ova smanjenja ne mogu biti znatna. Novom konstrukcijom moguće je:

- $\quad$ poboljšati mešanje sekundarnog vazduha i gasa koji dolazi iz gasifikacione komore,

- pojednostaviti konstrukciju vatrostalne ploče koja deli zone gasifikacije i zonu sagorevanja gasa,

- $\quad$ sniziti temperaturu plamena da bi se snizila temperatura sagorevanja, a time i emisija NOx, i

- pojednostaviti konstrukciju ložišta.

U tu svrhu predložena su dve varijante novog rešenja po ugledu na reference $[10,11]$. Slika 6. i slika 1. C prikazuju princip predloženog rešenja. Umesto međukomore (detalj 7 na slici 1 . C) predlo-žen je umetak od vatrostalne keramike. On igra ulogu međukomore, utiče na veće odavanje toplote plamena i pojednostavljuje konstrukciju ložišta smanjujući količinu utrošenog materijala i broj operacija pri izradi kotla. Vatrostalni umetak svojim oblikom treba da: omogući komadima koji ispadaju iz zone gasifikacije da se na njemu zadrže i potpuno sagore, poboljša transfer toplote na vodu i svojim oblikom obezbedi lako čišćenje ložišta. Oblik umetka treba da je takav da omogući ravnomerno strujanje u ložištu da nesagoreli komadići čvrstog gorivo ne bi bili uzneseni dimnim gasom. Takođe, jako je bitno da struja dimnog gasa ne uznosi nesegorele čestice sa vatrostalnog umetka, kao i da bude visoke temperature kad u njih ,udara“. U radu su simulirana brzinska polja dimnog gasa oko dve vari-jante vatrostalnog umetka u zoni sagorevanja, koje su prikazane na slici 7 .

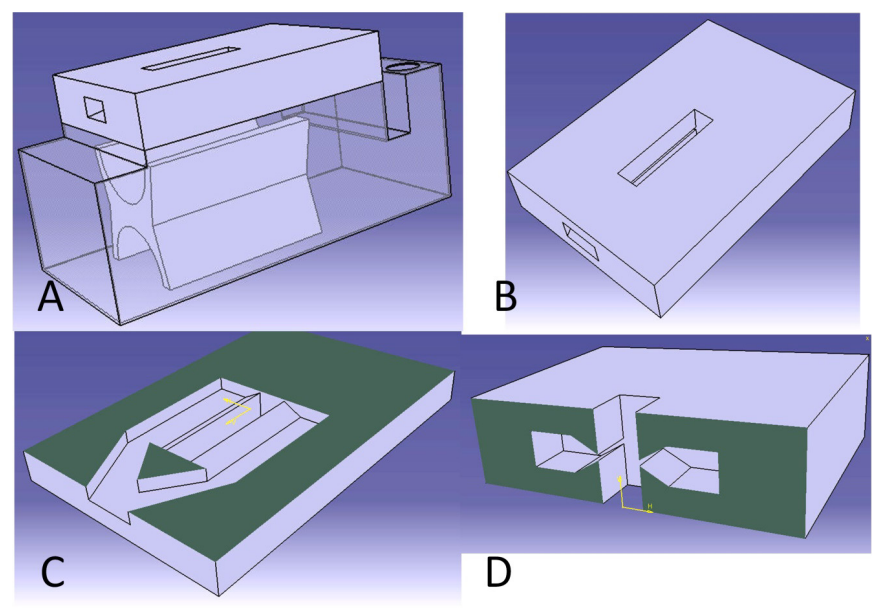

Slika 6: Ispitivani oblik ložišta kotla: A - izometrijski prikaz ložišta, B - izometrijski prikaz vatrostalne ploče koja deli zone gasifikacije i sagorevanja, sa presecima C i D koji prikazuju detalje kanala za ubacivanje sekundarnog vazduha

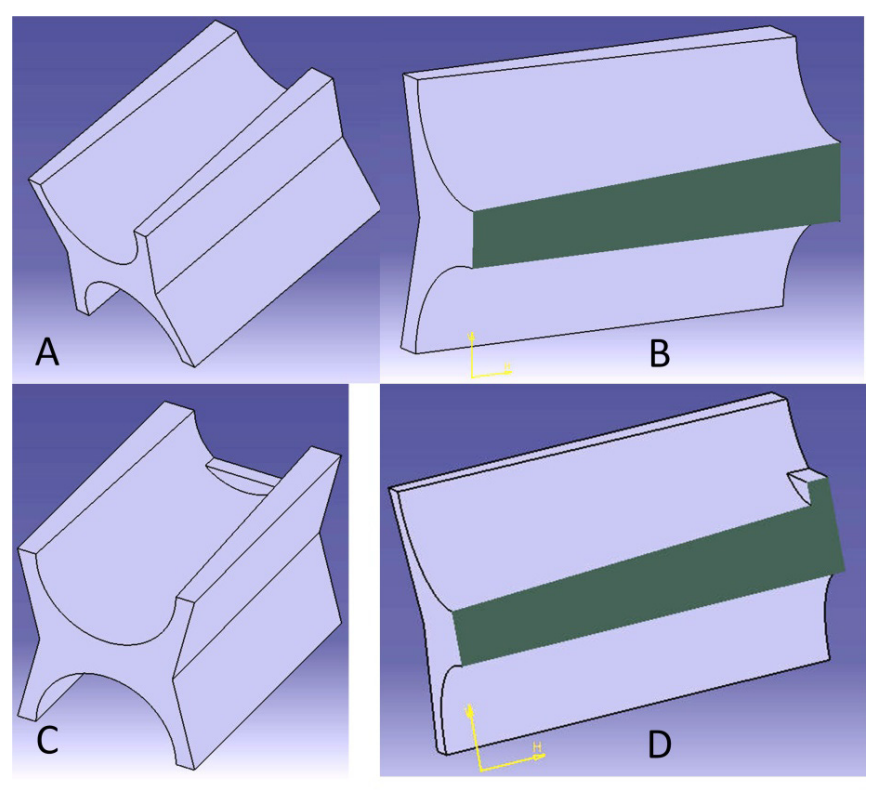

Slika 7: Vatrostalni umeci u ložištu. A i B su izometrisjki prikaz i presek 1. ispitivane varijante. C i D su izometrijski prikaz i presek 2. ispitivane varijante 
Slika 6. B, C i D prikazuje i predloženo pojednostavljenje konstrukcije kanala za sekundarni vazduh koji prolaze kroz vatrostalnu ploču koja deli zonu gasifikacije i zonu sagorevanja gasa (uporediti sa slikom 3. B, C i D). Umesto kružnih otvora predloženo je linijsko ubacivanje sekundarnog vazduha. Linijski otvori treba da omoguće jednostavniju izradu ploče i obezbede bolje mešanje gorivog gasa i sekundarnog vazduha, istovremeno smanjujući otpor strujanju vazduha. Ovde je važno reći da otpori strujanju primarnog i sekundarnog vazduha trebaju da budu istog reda veličine kako bi upravljanje bilo stabilno. Ako je npr. otpor strujanju sekundarnog vazduha mnogo niži od otpora strujanja primarnog veoma je teško da sistem automatskog upravljanja obezbedi stabilno sagorevanje u kotlu.

Dve ispitivane varijante vatrostalnih umetaka u ložištu prikazane su na slici 7. Oba rešenja imaju na gornjoj strani nagib prema prednjoj strani kotla (videti sliku 1. D i sliku 6. A), s tim da druga varijanta ima i jednu malu prečagu na zadnjoj strani (prema konvektivnom delu kotla) radi ravnomernije distribucije dimnog gasa u ložištu.

\subsection{Rezultat simulacija}

Slike 8. 9. i 10. prikazuju rezultate numeričkih simulacija. Simulirana je postojeća konstrukcija (slika 8.) i dve varijante analizirane konstrukcije (slike 9. i 10.).

Prilikom ispitivanja postojeće konstrukcije uznošenje velike količine nesagorelih čestica u gasnoj struji je identifikovano kao glavni uzrok povećanih emisija $\mathrm{CO}$ tokom rada (pikovi emisije $\mathrm{CO}$ prika-zani na slici 5.). Ključni parametar koji uzrokuje uznošenje čestica jesu brzine gorivog gasa. I ako su gasovi jako pokretljivi raspored brzina u zoni sagorevanja gorivog gasa pokazuje kvalitet mešanja go-rivog gasa i sekundarnog vazduha. Npr. ubacivanje veće količine vazduha na jednoj stani može da ima takođe negativan efekat kao i ubacivanje manje količine vazduha (kiseonika). Ukoliko su brzine uniformnije i ako je dovoljno dugo zadržavanje gorive smeše na visokoj temperaturi manja je verovatnoća većih emisija nesagorelih organskih jedinjenja a samim tim i emisije CO. Zbog toga je u analizama koje slede prioritet dat brzinskim poljima gorivog gasa, vazduha i dimnog gasa. Ono je modelirano na orignilnoj geomtriji uz pomoć 133176 čvorova i 688172 elementa. U programu Ansys CFX korićen je k-epsilon model uz pretpostvku da u ložištu vlada pritisak od 1 bar. Naravno da su kod svakog kotla osim brzinskog, bitna sva ostala polja (temperaturska, koncentraciona, pritiska) ali je ovde dat prioritet brzinskom koje je uzrok relativno visokih emisija CO. Cilj aktivnosti koje se opisuju bio je da se na najekonomičniji način i u najkraćem roku umanje pikovi (prikazani na slici 5.) i eventualno malo smanje prosečne emisije $\mathrm{CO}$ u radu. Za veće smanjenje emisija CO potrebno je uzeti u obzir sva polja od interesa kao i strujanje u zoni gasifikacije i sastav gasa sa količinom čestica koji iz nje izlazi. U o-vim analizama načinjena je jedna relativno gruba pretpostavka da gorivi gas struji ravnomernom brzinom kroz otvor koji povezuje komore za gasifikaciju i sagorevanje (videti sliku 1.) i njegov sastav je određivan preko kvazi ravnotežnog modela predstavljenog u referenci [15].

U poređenju sa predloženim konstrukcijama (slike 9. i 10.), postojeća konstrukcija ima veći otpor (zbog većih brzina) pri ubacivanju sekundarnog vazduha i neravnomernije polje brzina $u$ odnosu na linijsko ubacivanje vazduha. Pretpostavka je da neravno- merno polje brzina u zoni ubacivanja se-kunadrnog vazduha može da prouzrokuje lokalne zone sa viškom i manjkom vazduha (kiseonika) za sagorevanje a time i veće emisije CO. Interesantno je videti i polje brzina u međukomori i ložištu (slika 8. C i D). U prednjem delu međukomore brzinsko polje dimnog gasa favorizuje izbacivanje komadića u ložišni prostor (niži nivo). Tačnije komadići koji padaju u prednji deo komore biće izbačeni u donji nivo, komadići koji padaju po sredini proreza između komora sagoreće u međukomori, dok će oni koji padaju u zadnjem delu proreza između komora (ka konvektivnom delu kotla) ostati zarobljeni i sagoreće u međukomori. Ovo znači da je i međukomoru moguće geometrijski unaprediti. U ložištu ispod međukomore (videti sliku 8. C i D) brzinsko polje dimnog gasa pokazuje da su najveće brzine struja-nja pri dnu, što je nepovoljno jer favorizuje uznošenje pepela i nesagorelih čestica prema konvektivnom delu kotla.

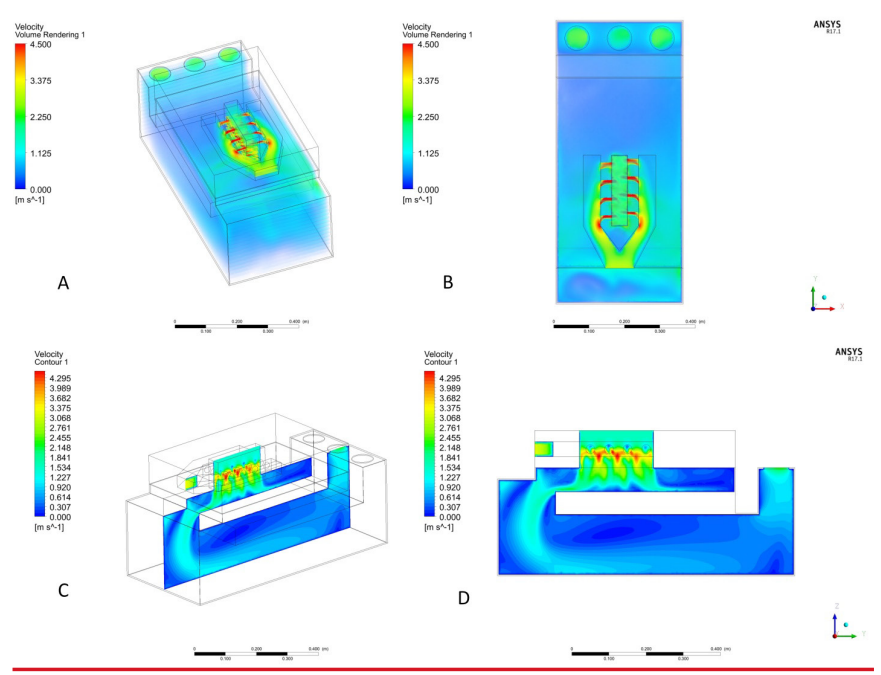

Slika 8: Brzinsko polje dimnog gasa u komori za sagorevanje ispitivanog kotla. A - trodimenzionalni prikaz strujanja u ložištu, B strujanje sekundarnog vazduha i strujanje u zoni sagorevanja gasa (horizontalni presek po sredini otvora za ubacivanje sekundarnog vazduha), C i D - vertikalni presk polja brzina dimnog gasa u ložištu (poprečni presek po uzdužnoj osi ložišta)

Slike 9. i 10. pokazuju da je u poređenju sa postojećim rešenjem (slika 8.), strujanje sekundarnog vazduha olakšano kroz ploču koja deli zone gasifikacije i sagorevanja. Ovde se još jednom skreće pažnja da mali otpor ubacivanja sekundarnog u odnosu na primarni vazduh može imati i negativan uticaj na kontrolu procesa sagorevanja kod ovakvih kotlova. Simulacija pokazuje da je brzinsko polje ravnomernjije što ukazuje na veću verovatnoću boljeg mešanja gorivog gasa i sekundarnog vazduha kod konstrukcija sa analiziranim vatrostalnim umetkom. Adekvatno rastojanje između vatrostalne plo-če i vatrostalnog umetka treba da omogući i nešto nižu temperaturu plamena u poređenju sa ispitivanim rešenjem, koja bi trebalo da utiče na snižavanje emisije NOx. Zbog toga što se struja dimnog gasa širi na više strana (videti sliku 9.) brzina dimnog gasa je niža i manja je mogućnost uznošenja čestica koje iz gasifikacione zone padaju na vatrostalni umetak. Brzinsko polje je nešto nepovoljnije kod vari-jante 1 (slika 9. C i D) u odnosu na varijantu 2 (slika 10. C i 
D) jer postoji „kratka veza“ prema konvektivnom delu kotla sa gornje strane vatrostalnog umetka. To znači da je bez obzira na nagnutost umetka moguće da sitnije čestice budu uznešene u struji dimnog gasa. Takođe, nepovoljno je da gorivi gas ima kratko zadržavanje u ložištu, što favorizuje varijantu 2 (slika 10 . C i D) u odnosu na varijantu 1 (slika 9. C i D) jer ona nema izraženu „kratku vezu“.

U poređenju sa ispitivanim kotlom (slika 8.), brzinsko polje dimnog gasa u ložištu rešenja koje imaju vatrostalni umetak (slike 9. i 10.) pokazuju još dve prednosti. Prva je što umetak favorizuje veće brzine uz površine uz koje struji voda pa time i koeficijent prelaza toplote, a druga je što su brzine u zoni taloženja pepela u dnu ložišta niže pa bi trebalo da je i manje uznošenje čestica u struji dimnog gasa.
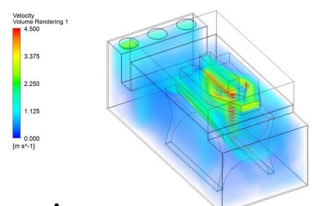

A
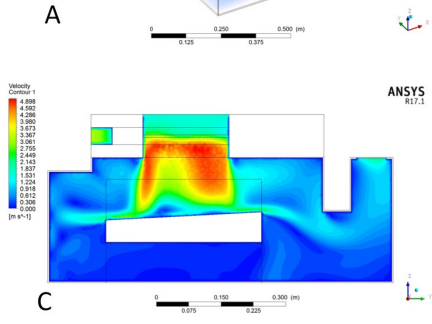

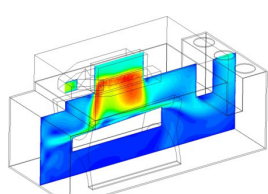

B

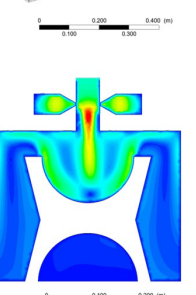

$\underset{\text { ANSYS }}{\text { RY: }}$

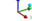

ANSYS

Slika 9: Brzinsko polje dimnog gasa u komori za sagorevanje sa prvom varijantom predloženog vatrostalnog umetka. A - trodimenzionalni prikaz brzinskog polja u ložištu, B i C - brzinsko polje u vertikalnom podužnom preseku kotla (presek po uzdužnoj osi otvora gasifikacione komore) i D - brzinsko polje u poprečnom preseku ložišta (presek po poprečnoj osi otvora gasifikacione komore)
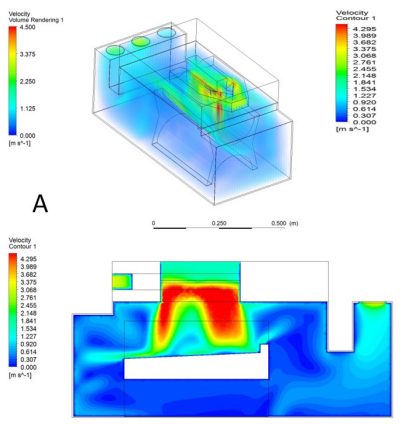

C
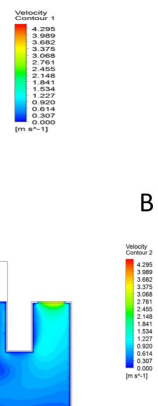

D
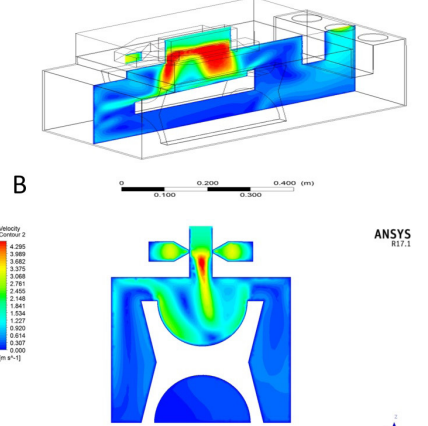

$-1$
ANSYS

$\therefore$
Slika 10: Brzinsko polje dimnog gasa u komori za sagorevanje sa drugom varijantom predloženog vatrostalnog umetka. A - trodimenzionalni prikaz brzinskog polja u ložištu, B i C - brzinsko polje u vertikalnom podužnom preseku kotla (presek po uzdužnoj osi otvora gasifikacione komore) i D - brzinsko polje u poprečnom preseku ložišta (presek po poprečnoj osi otvora gasifikacione komore)

Neadekvatno postavljanje vatrostalnog umetka moglo bi veoma nepovoljno da se odrazi na polje brzina dimnog gasa u ložištu, što je još jedna od činjenica o kojoj treba da se vodi računa pri projekto- vanju.

\section{Zaključak}

Ispitivana konstrukcija gasifikacionog kotla na ogrevno drvo je imala emisije CO $622.97 \mathrm{mg} / \mathrm{Nm}^{3}$ i NOx $273.42 \mathrm{mg} / \mathrm{Nm}^{3}$. Ove emisije zadovoljavaju standard EN 303-5 ali su još uvek visoke i moguće ih je smanjiti dvojako: promenom algoritma upravljanja i konstruktivnim izmenama kotla.

Promenom načina automatskog upravljanja pri otpočinjanju rada i pri smanjenju količine goriva u kotlu moguće je eliminisati pikove emisije i sniziti prosečnu emisiju CO za oko 20\% (vidi se na slici 5. kad se eliminšu pikovi i uporedi odnos prosečnih i trenutnih vrednosti emisije). Pri otpočinjanju rada regulišuća klapna sekundarnog vazduha treba da budu u nominalnom radnom položaju dok klap-na koja reguliše protok primarnog vazduha treba da je potpuno otvorena. Iz ovih položaja je potrebno uvesti kotao u nominalni radni režim. Pri smanjenju količine goriva u gasifikacionoj zoni javlja se povećani protok primarnog vazduha. Dakle, ako se klapna sekundarnog vazduha zatvara, a količina kiseonika u dimnom gasu se povećava tada ventilator koji izbacuje dimne gasove iz kotla treba da sma-nji brzinu ili klapna primarnog vazduha treba da se zatvara (prigušuje protok primarnog vazduha). Eksperimentalnim ispitivanjima utvrđeno je da nedostaje i tzv. fino podešavanje odnosa gori-vo/vazduh kako bi se dobila količina kiseonika u dimnom gasu, pri kojoj, za datu konstrukciju kotla emisije zagađujućih materija imaju najnižu vrednost.

Smanjenje emisija CO i NOx moguće je i pojednostavljenjem konstrukcije kotla. Numerička analiza izvršena u radu sugeriše da je to moguće izvesti izbacivanjem međukomore i ubacivanjem vatrostalnog umetka u ložište. Ovaj umetak može značajno da uprosti konstrukciju metalnog dela kotla i ima zadatak da: prihvati i sagori čestice koje dolaze iz zone gasifikacije, omogući taloženje čestica u ložištu, poboljša razmenu toplote i obezbedi nesmetano čišćenje ložišta. Pri postavljanju vatrostalnih umetaka treba biti oprezan jer njihovo malo pomeranje se može nepovoljno odraziti na brzinsko polje. Od dva simulacijama ispitivana, vatrostalni umetak koji je smanjivao protok najkraćom putanjom iz ložišta (prikazan na slici 10.) pravio je povoljnije brzinsko polje dimnog gasa u njemu.

\section{LITERATURA}

[1] Lund, H., S. Werner, R. Wiltshire, S. Svendsen, J. E. Thorsen, F. Hvelplund, B. V. Mathiesen, 4th Generation District Heating (4GDH) Integrating smart thermal grids into future sustainable energy systems, Energy, Volume 68 (2014), pp. 1-11.

[2] http://www.srbija.gov.rs/vesti/dokumenti_sekcija.php?id=45678 (accessed May 2018)

[3] Johansson L. S., B. Leckner, L. Gustavsson, D. Cooper, C. Tullin, A. Potter, Emission characteristics of modern and old-type residential boilers fired with wood logs and wood pellets, Atmospheric Environment, Volume 38 (2004), pp. 4183-4195.

[4] Deng, L., D. Torres-Rojas, M. Burford, T. H. Whitlow, J. Lehmann, E. M. Fisher, Fuel sensitivity of biomass cookstove performance, Applied Energy, Volume 215 (2018), pp. 13-20.

[5] https://www.viessmann.ch/de/wohngebaeude/Festbrennstoffkessel/holzkessel/vitoligno-250-s.html (accessed May 2018) 
[6] US 9,273,861 B1 (2016)

[7] US 2013/0186313 A1 (2013)

[8] US 2016/0290747 A1 (2016)

[9] https://www.solarbayer.com/Wood-boiler-HVS-E-LC.html

[10] US 8,640,655 B2 (2014)

[11] https://luuma-energy.de/Scheitholzkessel-LUUMA-SH18kWund-SH27kW-50cm-Scheitholzlaenge (accessed May 2018)

[12] http://www.radijator.rs/ (accessed May 2018)

[13] https://www.ecn.nl/phyllis2/Biomass/View/60 (accessed May 2018)

[14] Jankes, G., M. Stanojević, M. Karan, Industrijske peći i kotlovi, Mašinski fakultet, Beograd, Srbija, 1996.

[15] Karamarkovic, R., Karamarkovic, V., Energy and exergy analysis of biomass gasification at different temperatures, Energy, 35, Volume 2 (2010), pp 537-549

\section{Autor}

Rade KARAMARKOVIĆ

Fakultet za mašinstvo i građevinarstvo u Kraljevu Univerziteta u Kragujevcu

karamarkovic.r@mfkv.kg.ac.rs

Đorđe NOVČIĆ

Fakultet za mašinstvo i građevinarstvo u Kraljevu Univerziteta u Kragujevcu

Miloš NIKOLIĆ

Fakultet za mašinstvo i građevinarstvo u Kraljevu Univerziteta u Kragujevcu

Miodrag KARAMARKOVIĆ

Siemens AG Austria, Power and Gas,

Vienna, Austria

Dragiša ŠIMUNOVIĆ

Fakultet za mašinstvo i građevinarstvo u Kraljevu Univerziteta u Kragujevcu

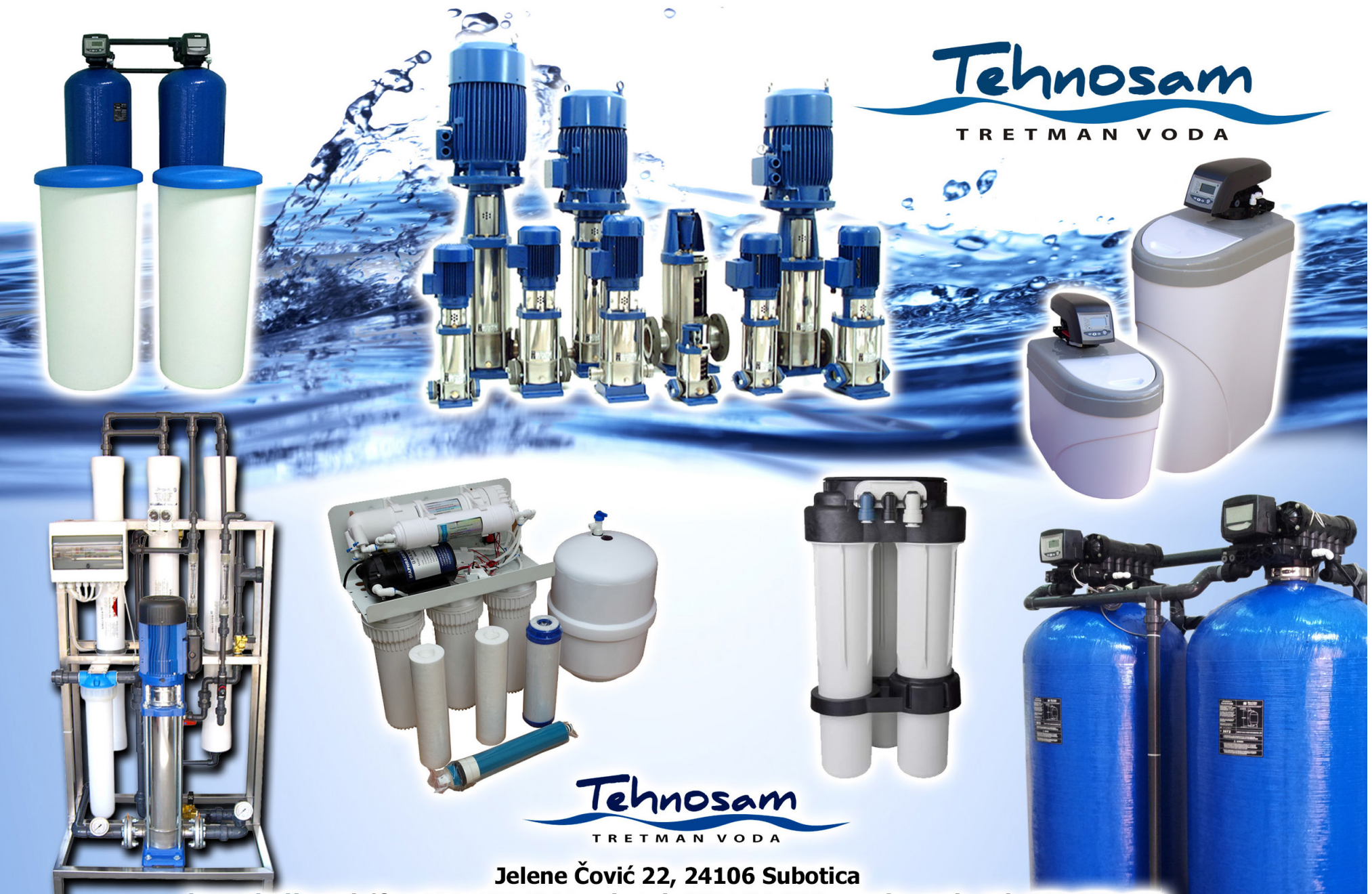

